\begin{tabular}{|c|}
\hline $\begin{array}{l}\text { Proceedings of the Institution of } \\
\text { Civil Engineers } \\
\text { Engineering Sustainability 161 } \\
\text { June } 2008 \text { Issue ES2 } \\
\text { Pages II }-122 \\
\text { doi: } 10.1680 \text { /ensu.2008.161.2.1 I3 }\end{array}$ \\
\hline $\begin{array}{l}\text { Paper 700017 } \\
\text { Received 16/05/2007 } \\
\text { Accepted 26/11/2007 }\end{array}$ \\
\hline $\begin{array}{l}\text { Keywords: } \\
\text { public health/sewage treatment \& } \\
\text { disposal/water supply }\end{array}$ \\
\hline
\end{tabular}

disposal/water supply

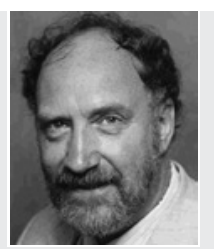

Christopher Shirley-Smith Director, Water Works UK Ltd, London, UK

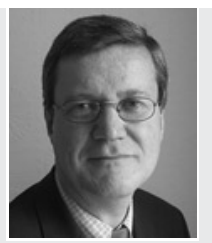

David Butler Professor of Water Engineering Director, Centre for Water Systems, University of Exeter, UK

\title{
Water management at BedZED: some lessons
}

\section{Shirley-Smith MSc and D. Butler MSc, PhD, DIC, CEng, CEnv, FICE, FCIWEM, FHEA}

The Beddington zero fossil energy development (BedZED) in London, UK, is something of a modern icon in terms of assembling simultaneously on the same site new construction methods, the best of available 'green' technology and social engineering combined with new peri-urban lifestyles. The development also includes a number of 'alternative' water systems. As with many innovative and exploratory departures, however, not everything went according to plan. This paper describes the bold vision, highlights some of the issues and seeks to learn and disseminate lessons for the future, with special reference to the integrated water and wastewater services.

\section{INTRODUCTION}

The Beddington zero fossil energy development (BedZED) is a mixed-use housing scheme in south London initiated by BioRegional Development Group (a Sutton-based environmental non-governmental organisation) and Bill Dunster Architects, a local firm, which provided the sustainable architecture input. BedZED has been developed in further collaboration with London's largest housing association, The Peabody Trust (the client) and the London Borough of Sutton (the original landowner). The scheme comprises 82 homes and $2500 \mathrm{~m}^{2}$ of commercial or live/work space (Fig. 1). The scheme was completed and occupied in 2002. ${ }^{1}$

BedZED is currently widely quoted in the literature on sustainability in building as a model assemblage of many best technical and social practice examples for new urban housing (for example, the House of Lords report on water management ${ }^{2}$ ). Indeed, many aspects of the planning and construction of the BedZED estate are highly innovative, imaginative and have attained various degrees of success and acclamation. It was a bold step forward on the part of the development partners to implement many aspects of diverse research that had been previously undertaken in building methods. Nowhere else in the UK had so many innovative elements previously been brought together on the same site, and this includes the water and wastewater management systems.

Furthermore, BedZED also aspires to be a new social model with a number of 'green' lifestyle practices designed to forge a sense of community: an electric car pool, a small clubroom, a full range of recycling facilities, a fresh vegetable delivery system and on-site sports facilities.

Despite the high publicity that BedZED received during its construction and early occupation, subsequent reviews of the development (for example Slavin ${ }^{3}$ ) have made more critical assessments of its viability as a model for future housing, and opposing points of view have since developed between BioRegional and the architect as to the percentage contribution the different so-called embodied (such as energy) and social 'green' elements have made to overall carbon reduction.

More generally, in the UK, progress towards sustainable development is gathering pace. Recent government initiatives include publication of the UK government's 2005 Sustainable Development Strategy, ${ }^{4}$ the 2006 Code for Sustainable Homes ${ }^{5}$ and the formation of the Communities England Agency in 2007. It is increasingly argued that water management solutions for new residential developments should be based increasingly on sustainability considerations owing to their far-reaching social, economic and environmental implications. ${ }^{6,7}$ Butler et al. ${ }^{8}$ present the case for water cycle management, looking to exploit the benefits of integration, much as has been espoused at BedZED.

Sections 2 to 5 of the present paper concentrate on reviewing the history of the development of the water management systems at BedZED over a period of approximately three years and highlights the sometimes conflicting objectives of different contributing parties. Section 6 highlights key practical lessons drawn from the project, and section 7 offers some recommendations for future practice on innovative sites. Conclusions are presented in section 8.

The paper does not attempt to discuss the broader aspects of energy conservation or carbon emissions reduction at BedZED. Suffice it to say that increased building insulation, the judicious use of solar absorption by mass concrete bodies, ventilation heat exchange and minimal supplementary heating are at the core of the development's construction. Sustainable water management was considered also to be of significance in contributing to the overall energy conservation strategy.

\section{BACKGROUND}

BedZED is the result of a lengthy gestation process and an integrated interdisciplinary collaboration. The physical concept 


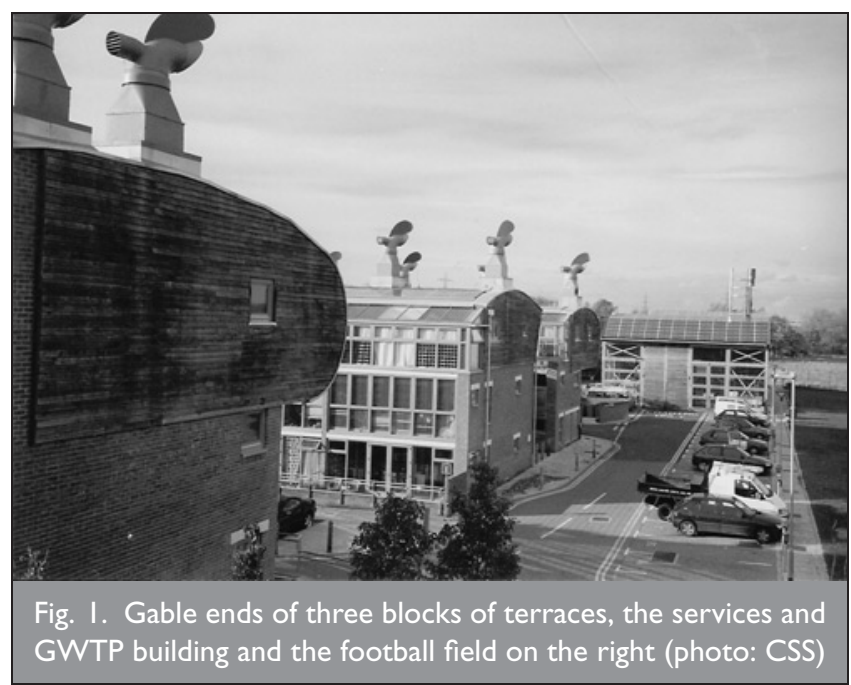

of BedZED is essentially the vision of architect Bill Dunster, and based on the principles he has personally put into practice in building his own residence 'Hope House' in East Molesey, South London. Gardiner \& Theobald (project and cost manager) joined the team at an early stage to oversee costing and subsequently site management. BioRegional found the site and approached The Peabody Trust as co-developer. Arup was selected as engineer for the project. Writing in 2001, Hartman was able to claim: 'at BedZED, The Peabody [Trust] is getting a greener building with lower maintenance and operating costs for the same capital cost as a conventional project. Add to that that you can live, work, exercise and shop on site, thereby reducing transport and food miles, and you've got not only energyefficient housing, but a carbon neutral development'. ${ }^{9}$

\section{WATER MANAGEMENT STRATEGY}

\section{I. The original concept}

The water management strategy for BedZED as originally developed by Arup, Bill Dunster Associates (BDA) and BioRegional was based on a four-fold approach.

(a) To reduce the overall consumption of potable water by the installation as standard, of water efficient appliances (lowflush toilets, aerated showerheads, spray taps and grade A rated washing machines) [13] throughout the development. This would reduce consumption automatically (and 'painlessly') and 'encourage water efficient lifestyles'. ${ }^{1}$ (The bracketed numbers here and throughout refer to the lessons learnt set out in Table 1. See section 6.)

(b) To make occupants aware of and take responsibility for their own water consumption and be able to monitor it. Therefore a visible, easy-to-read water meter (together with an electricity meter) [13] was provided in a small glass-fronted cupboard in the kitchen of all residential units at eye level (Fig. 2). This water meter was also wired for remote reading, hence eliminating the requirement for personal visits by the water supply company.

(c) To install a rainwater harvesting (RWH) system by draining surplus water from the slightly arched green roofs (consisting of peat-substitute sedum matting and drainage layer applied over the concrete roof shell) via a simple filter system into an underground tank under each of the 'blocks' of the development, which would store $35 \mathrm{~m}^{3}$ of water per block to supply the toilets and water the elevated 'sky' gardens for each of the elevated flats, adequate for approximately 11 weeks' supply ${ }^{10}[6,8]$. A supplementary reason for this was to 'manage surface water runoff to minimise local hydrological impact ${ }^{1}$ and to provide insulation and visual amenity.

(d) To install a 'Living Machine' (LM) (as designed by Living Technologies (LT)) in a greenhouse located in the BedZED services building for the purpose of full on-site waste water treatment [2] which would

(i) supply treated effluent for landscape irrigation and the sports field

(ii) supply treated effluent for reuse in the toilets in the clubhouse and elsewhere as appropriate

(iii) act as a small botanical nursery and an educational resource for the site and residents

(iv) grow plants in the LM for the production of essential oils. $^{11}$

At this point in time (c. 2000) the treated effluent was not considered as being the foundation of the non-potable supply, but as auxiliary, presumably to top up the RWH system as and when required.

In order to equip the LM with the tanks required for their design, LT was proposing to transport the steel containers from a site in Sardinia where they had previously been installed. This did not sit easily with the ethos of the BedZED sustainable procurement policy which stated that all materials, as far as reasonably possible, should be sourced within a $50 \mathrm{~km}$ radius of the site. This was one reason for later rejecting the steel tank proposal.

What had not been agreed between the client and other parties at this early stage was who was to manage the LM once installed, and who would take responsibility for the delivery of water and waste water services to the residents of BedZED. Nor had the issue of billing for these services been taken into consideration.

\subsection{The engagement of Albion Water Ltd}

Albion Water Ltd (AWL) became involved with the scheme in July 2000. Albion Water was the sole Ofwat-licensed water company in England and Wales at the time other than the major incumbent suppliers of water and wastewater services. It was agreed with The Peabody Trust that AWL would become the licensed water and wastewater services provider for BedZED, in conjunction with AWL's joint venture partner South West Water plc.

AWL's revised proposal, which aimed to reduce transport and energy management costs, was more radical than the original in a number of respects.

(a) AWL contracted with the client to build and manage all water (potable and non-potable) and waste water services as set out in Table 2 in the first instance under an 'inset appointment' [20] as an integrated system. (An inset appointment is the route by which one company replaces the incumbent as the appointed water and/or sewerage company for a specified area (www.ofwat.gov.uk/aptrix/ ofwat/publish.nsf/Content/insetappointments1205).) 
I) The overall concept as a pilot experimental project for small-scale supply of water and waste water services

2) The greenhouse concept

- Architectural vision

- Reduce land footprint by putting greenhouse on first floor level

- Visitor attraction and education facility

- Recycling of waste water

- Gravity flow to green water tanks

3) On-site GWTP concept

- Hybrid between activated sludge treatment plant and Living Machine

4) GWTP (backup)

- Emergency connection to main sewer was available as fallback position

5) Green water concept

- Visual differentiation from potable water by tinting light green with vegetable dye

- Green MDPE pipework (see 6)

- Adoption of green water standards (see 9)

6) Underground green water storage tanks

- Sized for long-term storage of rainwater (originally intended co-use as low-grade heat stores)

7) Green pipework

- Specified for green, non-potable supply.

- Non-compatible sizes with standard copper pipe to avoid cross-connection

- Full reticulation

8) Green roof concept

- Storm water attenuation

- Rainwater harvesting

9) Discharge consent from GWTP

- Obtained from Environment Agency for surplus green water to local environment, thus indirectly setting a local green water standard

10) Green water standard

- Agreement with environmental health officers at London Borough of Sutton endorses private supply and green water standard

II) GWTP: Construction

- All tanks and decking fabricated from 'same dimension' new timber from certified source within prescribed distance radius

- Two identical parallel wastewater treatment streams

- Installation looks very attractive and 'businesslike' (Fig. 5)
- Independent water company (Albion Water) engaged too late in process to fully influence integrated design

- Mistiming of infrastructure installation in project construction process

- Extra energy required for pumping liquor to first-floor green water treatment plant (GWTP) from settlement tank under football field

- Certain health and safety restrictions on visitors

- Leakage problems with greenhouse floor into work spaces beneath

- Financial viability: it was recognised from the outset that the GWTP was unlikely to be profitable at this scale

- Requirement for manual diversion to sewer (automatic fail safe was too expensive)

- Timing of installation of all water supply and drainage systems

- Some leakage in installation of green pipework (contractor unfamiliar)

- Tanks considerably oversized for final use as non-potable supply storage

- Storage time for green water too long (but no known degradation apart from contamination from other sources)

- Some problems in installation causing minor leaks: probably human error owing to unfamiliar procedures with patented jointing tools

- High E.coli contamination levels in storage tanks by rainwater from roofs required diversion to drain (later traced to animal fertiliser on roofs)

- Strong colour leaching (peat substitute) from green roof substrate into tanks/ toilets caused poor service for customer

- Obtaining agreements with the incumbent potable water and sewerage undertakers (different companies)

- Finalising contract for water supply and sewerage with main site leaseholder (Peabody Trust)

- Adoption of services

- Difficulties of working with recycled timber identified at early stage (septicaemia on hands), hence use of new timber

- Being on first floor led to difficulty of access for staff and materials

- Architectural design problems including long delays owing to faulty greenhouse floor
- Engage water and waste water provider and operator at pre-planning stage

- Ensure infrastructure is planned and installed at earliest opportunity

- Consider if necessary to put a GWTP on first-floor level

- If using plants as part of the filtration system, then a greenhouse is probably necessary

- Occasional guided tours good for community relations

- GWTP probably not financially viable until servicing around 200 units

- If financially feasible, automatic failsafe diversion to sewer (if available) is essential. Alternatives, if not

- Ensure installation contractor familiar with green pipework systems and the implications of working with treated effluent

- Agree green water standards that are consistently attainable

- Tanks need to be more accurately sized as part of the integrated initial design

- Contractor requires comprehensive training in new materials and approach

- Green pipework and associated fittings for non-potable water should become industry standard

- Advisable not to store rainwater drained through green roof installations without supplementary treatment and possibly post-storage disinfectant

- Standard roofs best for rainwater collection and reuse

- The green water standard can stand as precedent during development of a non-potable water national standard. Must negotiate well in advance with both the EA and LA

- As above. Essential to agree a national green water standard

- Relatively easy to work with similar material throughout. Wood is good to work and skilled carpenters are easier to find, cheaper and often more adaptable than plumbers who are normally untrained in this field 
12) GWTP: operation

- Two streams capable of being operated within different parameters

- Treating less effluent overall than sized for

13) Water conservation measures on the potable supply

- Remotely read water meters in kitchen enabling self-monitoring and electronic billing

- Spray taps: effective

- Showers in baths

- Dual flush toilets (2/4 litre) Some initial blockages of sewers caused by lower flow, now working satisfactorily

- Washing machines (provided, same machine throughout development): reliability and water consumption not yet monitored in practice

14) Sky gardens

- Sub-surface trickle irrigation systems installed

15) Costs

Capital

- Built to budget (see Table 3)

Operating:

- Higher than anticipated (energy, labour, extra equipment, water quality testing)

16) Residents

- Appear to be excited by the system and supportive of GWTP concept

- Values of property are reported to be $15 \%$ higher than similar adjacent properties ${ }^{3}$

- Differential charges for potable and green water (@ 90\%)

- Average combined charges for water and sewerage $=£ 33.50$ per person per annum

17) Savings recorded at BedZED

The projected estimated use of water at BedZED ${ }^{10}$ was between 55 I/head.day ('enthusiastic house') and $92 \mathrm{l} /$ head.day ('typical house').

Records indicate a measured average of $95.6 \mathrm{I} /$ head.day across the development.

18) Is BedZED sustainable over:

- 5 years $/ 10$ years $/ 20$ years?

- Is it a step too far?
- Higher energy budget than expected

- Requires regular labour input

- Did not achieve consistent effluent at green water standard hence not regularly meeting consents at time of AWL withdrawal

- Denitrification causing problems with sludge bulking leading to pipe blockages and flooding

- Electronic monitoring system of meters did not satisfactorily perform throughout: manual reading still required. Whether residents use them to self-regulate their consumption is not yet known (probably not many)

- Installed model is bulky and unattractive

- May not be entirely effective, requiring more than one flush: not tied in with volume of green water available (which could provide for a $3 / 6$ litre model)

- At least one resident moved out taking washing machine with them. No guarantee that it will be replaced by machine of equal efficiency

- Rainfall monitors and automatic supply pumps not working

- Danger of overwatering (or lack of water in event of malfunction)

- Delays by both water and sewerage companies in reaching bulk purchase agreements. Ofwat was undecided about the inset status

- Initially run as private supply

- Have experienced a range of problems with water: leaks, no water from green water tanks, sky gardens not irrigated, meters not functioning, brown water (peat substitute) in toilet bowls

- Difficulty in setting up metering and billing systems resulted in long delays (and therefore accumulating charges) in collecting charges, which was not appreciated by residents

- There was an unquantified volume of undetected leakage from the network due to poor installation for a significant number of months which may account for a higher per capita consumption than was actually the case
- GWTP requires operator presence on a regular basis. The optimum situation is to have the GWTP running in such a way that the simple tasks can be carried out by the non-specialist service agent as part of their other duties on the development

- As price of water increases, access to such meters by the householder may become more important. Electronic remote metering for billing company is effective (when it works)

- Meters need to be redesigned so they cannot be disconnected!

- Design of efficient taps is important otherwise occupant may substitute for less effective ones

- In a fully integrated system, where the likely volume of green water is available, size flush volume to availability

- Investigate need to increase gradient on sewers

- Grade A machines provided. Should provide a bond to keep the machine in the house. Consider, for example, rental as part of service charge

- Simpler to allow gardeners to operate their own inlet valves on a demand basis

- Many unanticipated costs when pioneering new installations. Allow generous contingency sum in initial budget

- It is inevitable that there will be teething problems. Ensure that the system is well tested before occupants move in. Allow occupants occasional educational access to GWTP

- The establishment of effective billing systems for residents from the beginning of occupation is essential

- Water meters need to be accessible both to residents and utility companies. Sample metering to test remote reading system works is important

- Not yet known. Answer: probably

- Perhaps. But an important step 


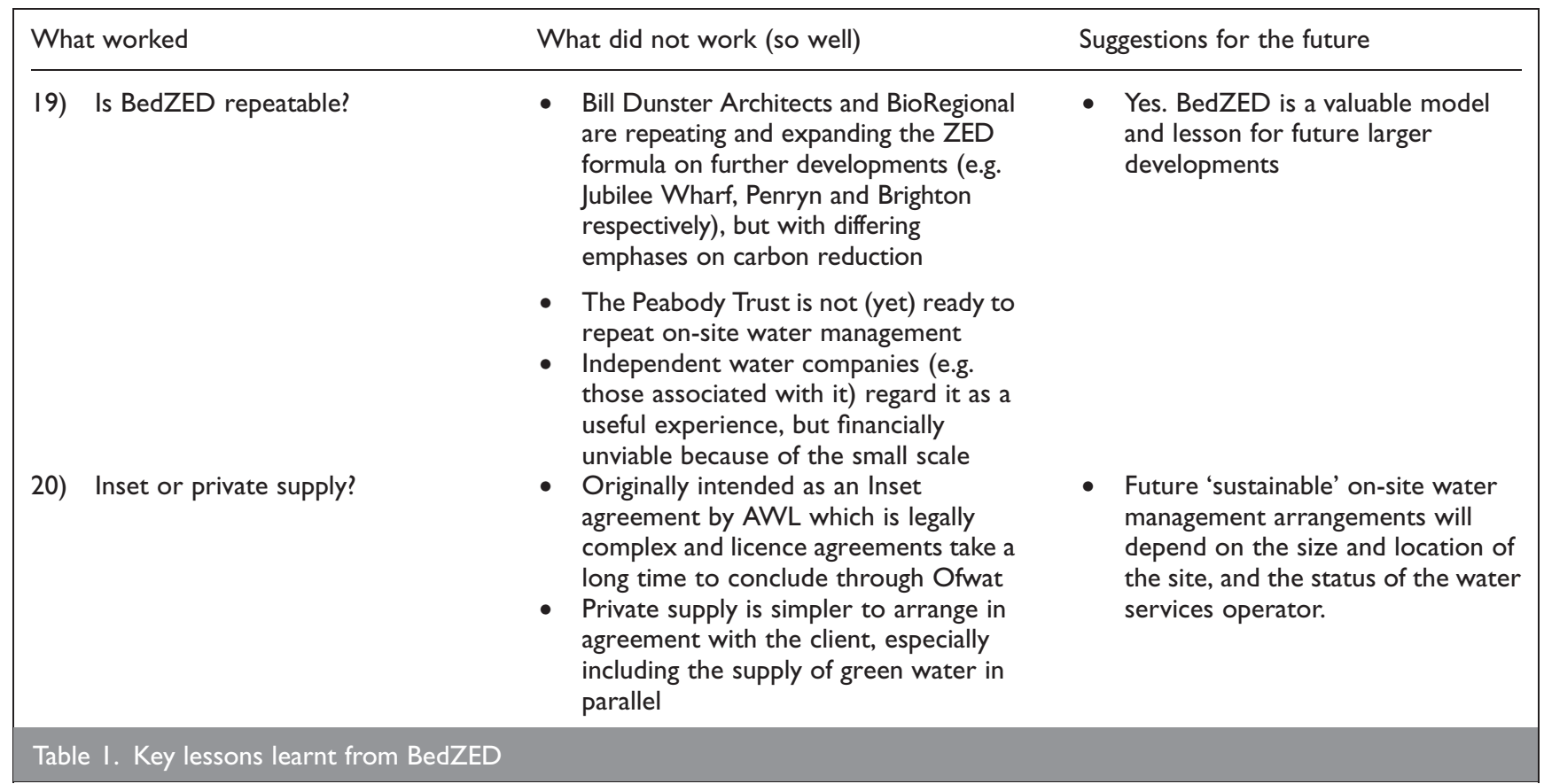

(b) AWL agreed to build a modified version of the LM to be known as the green water treatment plant (GWTP) [3] that would provide the necessary (non-potable) green water (water treated to a non-potable standard as specified in the Appendix.) for the flushing of all toilets, and the watering of the sky garden areas through the trickle irrigation technique [14]. This waste water treatment installation was to combine the strengths of an activated sludge treatment works with the more unusual, floating, raft-based plant purification system of the LM.

(c) AWL proposed to build the tanks for the GWTP on-site from locally sourced materials [11], thus eliminating the costs and environmental impact caused by long-distance transport of steel tanks.

(d) AWL contracted to liaise with the Environment Agency and the London Borough of Sutton Environmental

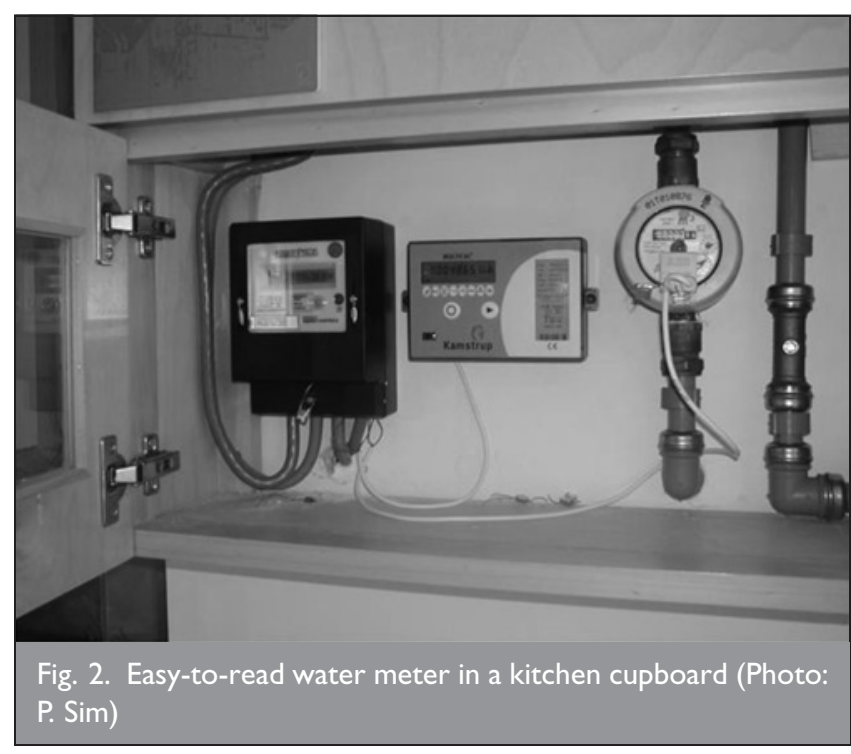

Health Department [10] to agree a suitable green water standard for the site (see Appendix) to which the GWTP would be required to conform and a discharge consent [9].

(e) The full scope of the responsibilities to be undertaken by AWL is set out in Table 2 .

AWL therefore inherited some of Arup's original concepts (e.g. RWH) and built on the proposals of LT by using the basic treatment train of the LM with some important modifications, mainly to try to reduce the operational energy consumption. The RWH system was left in place but was to cause problems at a later date.

\subsection{Albion Water's strategy for water management}

As a licensed water undertaker in its own right, AWL began negotiations with Sutton \& East Surrey Water plc for the latter to provide a bulk supply of potable water to the site boundary under an inset appointment [20]. AWL were to be the on-site distributors of potable water in parallel with a supply of 'green' water for the toilets. Additionally and simultaneously AWL entered negotiations with Thames Water plc for a connection to the main sewer adjacent to the site for use in emergencies and down time of the GWTP.

Figure 3 shows how the water management system (as built) at BedZED is arranged. The mains water supply enters the site via a bulk meter and is distributed in a conventional way directly off the pressurised main to all dwellings. Likewise waste water is initially collected in a conventional way and flows under gravity to a sump from where it is pumped to into a pair of large, compartmentalised primary settlement tanks arranged in series beneath the football field. The liquor from the settlement tanks is then pumped to the GWTP on the first floor in the green house where it flows through the treatment train (see Fig. 4). 


\begin{tabular}{|c|c|c|c|c|c|}
\hline No. & Sector & Adopt & $\begin{array}{l}\text { Replace at } \\
\text { end of life }\end{array}$ & $\begin{array}{l}\text { Operate/ } \\
\text { maintain }\end{array}$ & $\begin{array}{l}\text { Financial } \\
\text { responsibility for } \\
\text { replacement }\end{array}$ \\
\hline I & Potable water pipework & Yes & Yes & Yes & AWL \\
\hline 2 & Foul sewers & Yes & Yes & Yes & AWL \\
\hline 3 & Green water treatment plant & Yes & Yes & Yes & AWL \\
\hline 4 & Return green water pipework & Yes & Yes & Yes & AWL \\
\hline 5 & Emergency discharge sewer & Yes & Yes & Yes & AWL \\
\hline 6 & Green water storage, pumps and pipework & Yes & $\begin{array}{l}\text { Tank: No } \\
\text { Pump: Yes }\end{array}$ & Yes & $\begin{array}{l}\text { Tank: Peabody Trust } \\
\text { (PT). Pump: AWL }\end{array}$ \\
\hline 7 & Low-temp CHP pipework spine & Yes & Yes & No & PT \\
\hline 8 & $\begin{array}{l}\text { Connection of rainwater filters to green water } \\
\text { tanks }\end{array}$ & Yes & Yes & Yes* & PT \\
\hline 9 & Green water overflow to ditch & Yes & Yes & Yes* & PT \\
\hline 10 & Storm drainage serving dwelling, not covered by 8 & Yes & Yes & Yes* & PT \\
\hline II & Boundary ditch & No & No & No* & PT \\
\hline
\end{tabular}

The treated effluent is passed through a ultraviolet (UV) unit for disinfection, dyed green [5] and distributed through a return spinal pipe back to the green water storage tanks under each of the blocks. From here it is pumped on demand directly to the toilet cisterns of the dwellings, or used to irrigate the sky gardens. Surplus treated effluent is drained by gravity to a watercourse (ditch) at the boundary without being UV irradiated (an Environment Agency condition) [9]. Emergency connection to the main sewer was available as fallback position in case of system malfunction [4].

\section{THE GREEN WATER TREATMENT PLANT}

The GWTP at BedZED is essentially a hybrid system [3] of an extended aeration activated sludge treatment plant and the LM system as proposed by the late Lyle Schnadt of Living Technologies. The AWL engineer, David Triggs, was largely responsible for

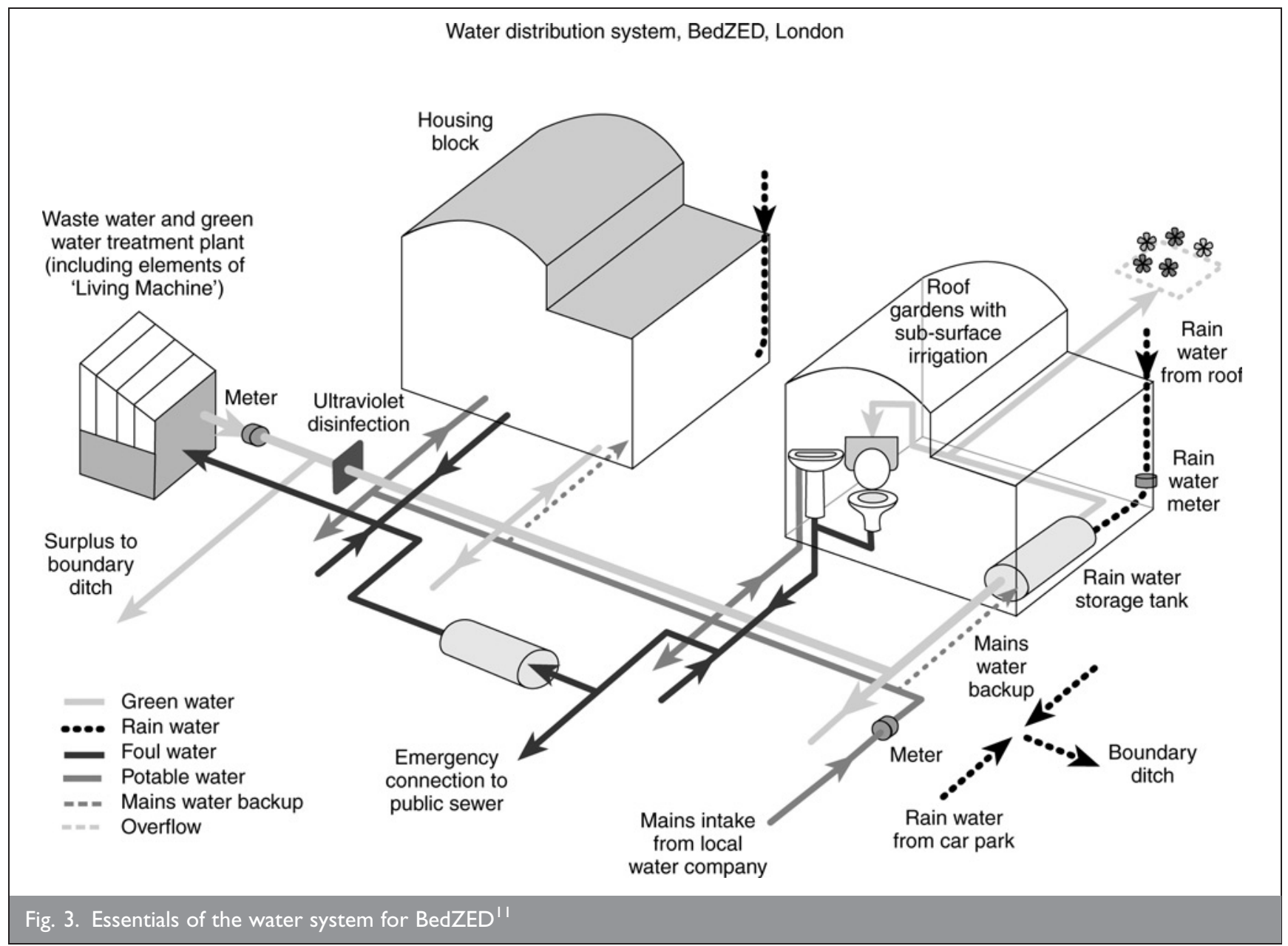




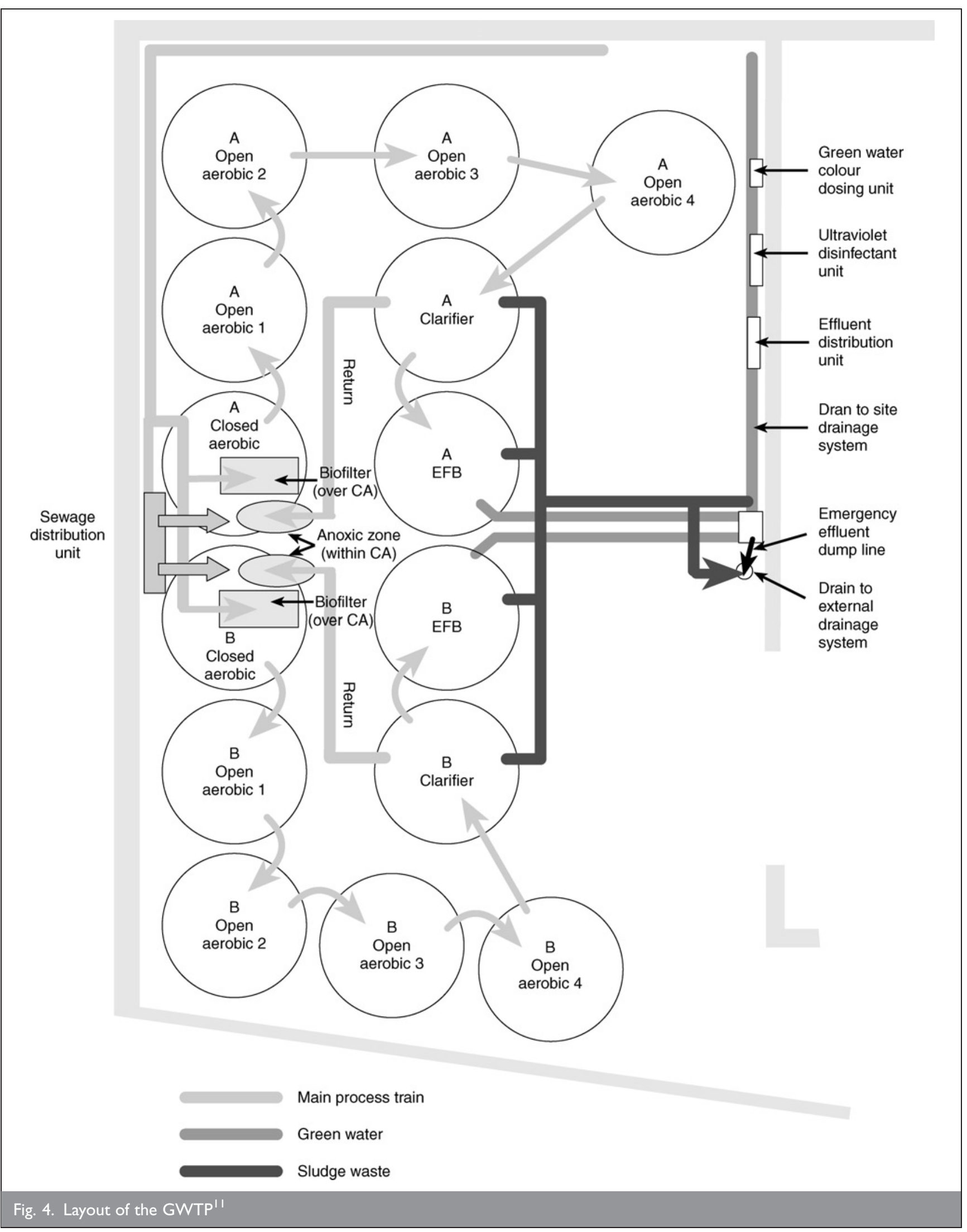

the design, construction and operation of the GWTP. The layout of the GWTP as finally constructed may be seen in Figs 4 and 5.

One important innovation introduced by AWL was to build two independent streams (A and B) into the treatment train [12], for a number of reasons (a) to allow one stream to be taken out of commission if necessary without affecting the overall efficiency of the plant (e.g. cleaning, malfunction)

(b) to allow for experimentation against a control

(c) to allow for extra treatment capacity if the site were to be expanded at a future date. 


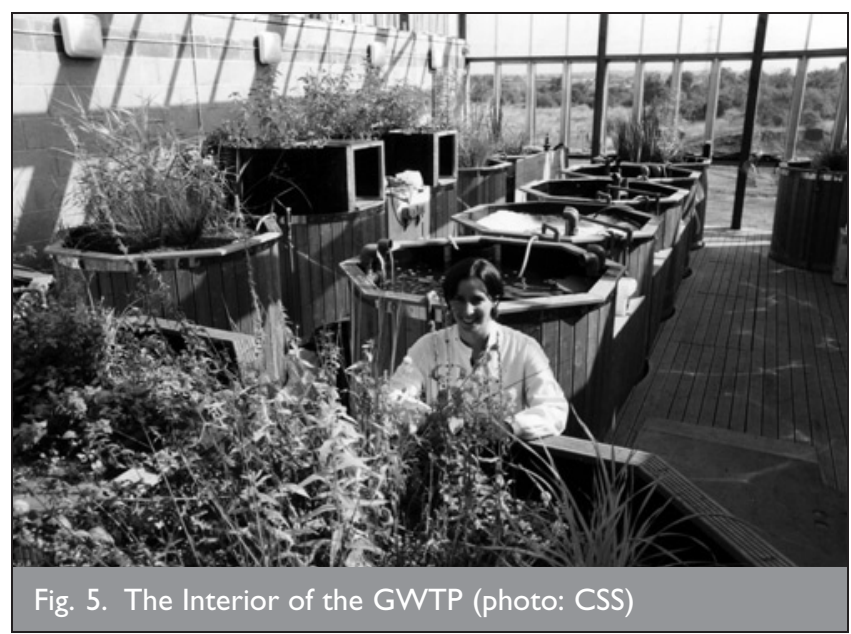

The GWTP was sized to treat $25 \mathrm{~m}^{3}$ of waste water per day and produced a similar volume of green water. In the event, this volume exceeded the required capacity, partly due to the effectiveness of the installed water demand management measures $[12,13]$.

Figure 5 shows the interior layout of the GWTP. The two anaerobic tanks with the substitute peat filters atop them may be seen centre left and the two trains of identical tanks disposed about the raised floor of the greenhouse are also clearly visible. The tanks themselves are approximately $2.5 \mathrm{~m}$ deep, built of wood [11], lined with butyl rubber and reinforced with exterior stainless steel bands. The decking stands at about $1 \mathrm{~m}$ above the greenhouse floor.

All distribution pipework for green water effluent from the GWTP consists of specially manufactured green-coloured MDPE pipes of non-standard diameters [7] for both visual identification and avoidance of cross-connection. A $63 \mathrm{~mm}$ diameter, spinal pipe links the GWTP to the underground storage tanks [6] and $20 \mathrm{~mm}$ green pipework feeds the toilet cisterns and sky garden systems throughout the development.

\section{WATER MANAGEMENT AT BEDZED AND SUSTAINABILITY}

The objective of the on-site water services installation at BedZED was to demonstrate the achievement of a significant decrease in overall and per capita water consumption by the residents [18] through

(a) equipping as standard the entire development with watersaving devices and appliances built to a known specification and performance [13]

(b) substituting a significant 'safe' proportion (c. 30\%) of domestic water with green water produced as an effluent from the on-site GWTP [17]

(c) reducing overall charges to the residents for water and waste water services by providing a 'lower' grade of water for non-potable purposes [16] at a reduced tariff

(d) demonstrating that small-scale integrated water management systems on new-build sites are practical, viable and make a significant contribution to reducing water demand [1]; the architect was clear that the GWTP should also be an educational facility and that there should
Construction element $£ 1000$

Greenhouse: includes glazed roof, openable lateral panels, drainage runs, service floor, blockwork walls

Green water treatment plant*: design, supply, install including all associated tanks, pipework, filters, blowers and commissioning

Settlement tanks (2): installation including excavation, formwork, concrete, backfill and all associated pipework and connections

Pipework for green water return and connections to rainwater storage tanks

General building contractor's costs, site setup, management, supervision, overheads, profit @ 10\%

Total waste water treatment and plant infrastructure distribution construction costs

*Supplied in-kind by Albion Water Ltd.

Table 3. Waste water treatment plant, infrastructure and distribution construction costs

be reasonable access for visitors and residents to see the process at work [2]

(e) engaging with residents in a number of other ways to make them aware of the water systems surrounding them, for example, the posting of small labels adjacent to the toilets and kitchen sinks asking them to assist in protecting the waste water system by not putting oils, used sanitary items and so on into WCs [16]

( $f$ ) gathering valuable research data based on real-time monitoring of treatment processes, water consumption and behavioural factors.

Additionally, BedZED offered an opportunity to assess projected and real costs for the building and operating of such a small-scale yet comprehensive system [15]. Since this type of service had never previously been offered on such a compact development, it was intended to provide a model and a benchmark against which to make a financial assessment of subsequent larger and thus more financially viable schemes. A breakdown of the infrastructure construction costs associated with the scheme, of which the client bore the majority, is given in Table 3, while AWL was financially responsible for the fitting out of the GWTP. At this time there are no meaningful operating costs available except that it was reported (verbally) that energy costs, largely stemming from increased aeration of the tanks, were projected to be higher than had originally been estimated.

In June 2003, owing to circumstances beyond their control, and not directly associated with the BedZED engagement, AWL and its subsidiary companies were dissolved and responsibility for the delivery of BedZED water management was assumed by South West Water (SWW). This enforced withdrawal by AWL occurred during the inevitable 'teething' period for an innovative system. Unfortunately, SWW was not in a position to continue to perfect the operation of the GWTP, principally due to a lack of expertise in and commitment to this type of treatment.

The practice of sustainability must of course be as robust as the theory to withstand long-term durability. In this instance, unfortunate financial realities intervened to curtail the development of this project to its full potential. At this time the 
GWTP is 'under reconstruction' and not producing green water (but see next section).

\section{KEY LESSONS}

One of the main objectives in scrutinising the BedZED experience is to disseminate those lessons which were hard learnt, and for which there should be no reason subsequently to duplicate the less successful aspects thereof. Table 1 sets out some 20 aspects of the project including the elements that 'worked', aspects that worked 'less well', and how these deficiencies might be corrected in the future. Rather than repeat these in detail here, the reader is invited to scrutinise Table 1.

At the tactical level, a number of miscalculations and misjudgements were made from the early stages of the project and these are discussed further in this section. A series of different parties were sequentially tasked with designing and making the system work: BDA envisaged an LM, Arup designed a combined rain water and recycled water system and Albion Water inherited an unworkable compromise system and had to redesign and build within existing constrained parameters.

The concepts of demand management, rain water harvesting, stormwater management, green water recycling and thermal heat storage combined within the same system were never reconciled, leading to oversized underground tanks, wasted treated effluent, large amounts of mains water top-up and uncertainty about the quality of water supplied for various purposes. Suitable tools to avoid this problem are only now emerging. ${ }^{10}$

Albion Water undertook to deliver BedZED's water supplies and waste water recycling plant in the knowledge that it would be commercially marginal, but that the BedZED GWTP would be an important and valuable demonstration project of sustainable technology for further development on new sites in different parts of the UK. The demise of the company (AWL), however, left BedZED residents and The Peabody Trust in a difficult position. SWW continued to provide basic statutory services for residents, but had little incentive to carry the GWTP through to a successful outcome. Thames Water has now undertaken a limited responsibility to restore the GWTP to specification standards while currently removing waste water through its own network. It also intends to install a membrane bioreactor as the principal treatment system.

Site management during the construction period had some inherent weaknesses and apparently difficulty was experienced in the simultaneous handling of the full range of new, 'sustainable' technologies being rolled out on the BedZED development. That such a task was daunting is no exaggeration. The difficulties were, however exacerbated by poor communication, delayed decision making, ill-timed construction programming, and some redundancies and closures of small companies engaged on the site owing to the ensuing delays.

Perhaps the most important lesson to emerge from BedZed is the need to appoint a single competent organisation that will take responsibility for all aspects of integrated water management and engage with the project sponsors in the planning process from the outset.

\section{RECOMMENDATIONS FOR FUTURE DEVELOPMENTS}

On the basis of experience gained at BedZED, the following recommendations can be made for future developments.

(a) To achieve the most successful progressive, sustainable and integrated solutions to on-site water, waste and recycled water management; and to select and engage the project life-time service delivery agent at the earliest opportunity (i.e. at the outset planning of the project).

(b) Under legislation provided by the Competition Act (1998) and the Water Act (2003), consider engaging independent competent service delivery agents capable of managing innovative approaches, which are not necessarily the local monopoly incumbent for water and waste water services.

(c) Develop a nationally accepted green water quality standard applicable to non-potable water systems.

(d) Understand clearly the water supply-demand balance on the site.

(e) Ensure that all participating parties in highly innovative projects are sufficiently competent, flexible and visionary to accommodate the new skills required with the traditional building approach. This may require more staff and resources than a conventional scheme until new protocols are established and generally accepted.

( $f$ ) Develop effective communication systems between different construction disciplines through progressive on-site project management techniques.

(g) Ensure sufficient financial contingency is available to meet the unexpected.

\section{CONCLUSIONS}

This paper has described the vision, history and development of the integrated water and wastewater services provided at BedZED. In particular, it provides an examination both of those elements of the system that were successful and those which have operated less well or not at all, in the hope of learning from them and disseminating lessons for the future. Part of the follow-up work at BedZED entails devising revised solutions and working with the landowners, namely The Peabody Trust, to implement them in full.

Only time and testing will tell whether all or some of the less conventional elements will make a substantial and enduring contribution to engineering sustainability. The bold steps taken in water management on the site may indeed have been 'a step too far', but nevertheless have provided a unique insight into the current feasibility envelope and what issues may be expected to present themselves once conventional boundaries are crossed.

\section{ACKNOWLEDGEMENTS}

The following organisations are duly acknowledged: Albion Water Ltd, Bill Dunster Architects, BioRegional Development Group, The Peabody Trust, South West Water plc, the Water Cycle 
Management for New Development (WaND) team and the residents of BedZED.

\section{APPENDIX: DEFINITION OF GREEN WATER AT BEDZED}

Green water is a generic description for water which

(a) has been treated to a grade suitable for provision as a nonpotable, secondary supply, usually, but not exclusively in parallel with a potable supply, for industrial, residential or public use (examples include toilet flushing, horticultural/ irrigation purposes, irrigation of sports pitches, public area cleansing, sewer jetting, laundries, industrial processes or washing, heating/cooling functions).

(b) has the following characteristics

(i) low turbidity (less than 2 NTU), low enteric microorganisms (less thatn $10 \mathrm{cfu} / 100 \mathrm{ml}$ ), conforms to criteria for tertiary treated effluent, typically less than $10 \mathrm{mg} / \mathrm{l} \mathrm{BOD}$, less than $10 \mathrm{mg} / \mathrm{l}$ suspended solids and less than $5 \mathrm{mg} / \mathrm{l}$ total ammonia

(ii) should be clearly identified as a separate supply, not for human consumption, by the use of a green tinged vegetable dye at a specified dilution (1:20 000)

(c) may include rainwater, surface water runoff, groundwater and other derivations of raw water, subject to meeting the above minimum standards

(d) should be distributed via a system of pipework, which is of a distinct green colour and particular diameter(s) or configuration readily identifiable and indexed in the building trade, and which through physical incompatibility cannot accidentally be cross-connected with a potable system.

\section{REFERENCES}

1. Lazarus N. Beddington Zero (Fossil) Energy Development: Toolkit for Carbon Neutral Developments-Part 2.
BioRegional Development Group, Department for Trade and Industry, 2003. Unpublished Report.

2. House of LoRds. Water Management. Vol. 1. Science \& Technology Committee Report. The Stationery Office, London, 2006.

3. SLAVIN T. Living in a Dream. The Guardian, Society section, Environment, 2006, p. 6, 17 May.

4. HM Government. Securing the Future. Delivering UK Sustainable Development Strategy. The Stationery Office, London, 2005.

5. Department for Communities and Local Government. Code for Sustainable Homes. A Step-change in Sustainable Home Building Practice. 2006. Available online from http:// www.planningportal.gov.uk/uploads/ code_for_sust_homes.pdf

6. Fenner R. A., Ainger C. M., Cruickshank H. J. and Guthrie $P$. M. Widening engineering horizons: addressing the complexity of sustainable development. Proceedings of the Institution of Civil Engineers, Engineering Sustainability, 2006, 159, ES4, 145-154.

7. Makropoulos C., Morley M., Memon F. A., Butler D., Savic D. and Ashley R. A decision support framework for sustainable urban water planning and management in new urban areas. Water Science and Technology, 2006, 54, Nos 6-7, 451-458.

8. Butler D., Balmforth D., McDonald A., Ashley R., Sharp E., Kay D., Packman J., JefFrey P. and SAVIC D. Managing the urban water cycle in new developments. Proceedings of 7th International Conference on Urban Drainage Modelling and 4th International Conference on Water Sensitive Urban Design, Melbourne, Australia, 2006, V1, 405-412.

9. Hartman H. This year's model. Building Design, Built Environment Supplement, 14-15 October 2001.

10. Ove Arup \& Partners. Rainwater Tanks for BedZED. Ove Arup \& Partners, 2000. Unpublished report.

11. Living Technologies. A Proposal to Ellis \& Moore for a Living Machine, 2000. Unpublished report.

\section{What do you think?}

To comment on this paper, please email up to 500 words to the editor at journals@ice.org.uk

Proceedings journals rely entirely on contributions sent in by civil engineers and related professionals, academics and students. Papers should be 2000-5000 words long, with adequate illustrations and references. Please visit www.thomastelford.com/journals for author guidelines and further details. 